\title{
Are comorbidities associated with long-term survival of lung cancer? A population-based cohort study from French cancer registries
}

\author{
A. Seigneurin ${ }^{1,2,3^{*}}$ (D, P. Delafosse ${ }^{1}$, B. Trétarre ${ }^{4}$, A. S. Woronoff $f^{5}$, M. Velten ${ }^{6}$, P. Grosclaude ${ }^{7,8}$, A. V. Guizard ${ }^{9}$, \\ B. Lapôtre-Ledoux ${ }^{10}$, S. Bara ${ }^{11}$, F. Molinié ${ }^{12}$ and M. Colonna ${ }^{1}$
}

\begin{abstract}
Background: Survival rates of lung cancer remains poor and the impact of comorbidities on the prognosis is discussed. The objective of this study was to assess if the Charlson Comorbidity Index (CCl) was associated with 8-year survival rates by histological type.

Methods: A cohort study was conducted using randomly selected cases from 10 French cancer registries. Net survival rates were computed using the Pohar-Perme estimator of the net cumulative rate. Three Cox models were independently built for adenocarcinomas, squamous cell and small cell cancers to estimate prognostic factors including $\mathrm{CCl}$ grade.

Results: A total of 646 adenocarcinomas, 524 squamous cell and 233 small cell cancers were included in the analysis. The net 8-year survival rate ranged from 12.6\% (95\% Cl: 9.8-15.4\%) for adenocarcinomas and 13.4\% (95\% Cl: 10.1-16.7\%) for squamous cell carcinomas, to 3.7\% (95\% Cl: 1.1-6.3\%) for small cell cancers. Observed and net survival rates decreased for $\mathrm{CCl}$ grades $\geq 3$ for all histological group considered.

After adjustment for sex, age group, stage and diagnostic mode, CCl grades 1 ( $H R=1.6[95 \%$ Cl: 1.1-2.3]), 2 ( $H R=1.7$ [95\% Cl: 1.1-2.7]) and $\geq 3$ ( $\mathrm{HR}=2.7$ [95\% Cl: 1.7-4.4]) were associated with lower survival rates only for small cell cancers.

Conclusion: After adjustment for age, sex, stage and diagnostic mode, the presence of comorbidity based on CCl grades $1-2$ and $\geq 3$ was associated with lower survival rates for small cell cancers whereas no differences were observed for adenocarcinomas and squamous cell cancers.
\end{abstract}

Keywords: Lung cancer, Prognostic factors, Net survival, Histological type, Population-based study

\section{Background}

Lung cancer is the leading cause of cancer and cancer death worldwide with 1.82 million new cases by 2012, representing $12.9 \%$ of all new cancers, and 1.6 million deaths (19.5\% of the total) [1]. In France, nearly 39,500 lung cancers were diagnosed and 30,000 individuals died from lung cancer in 2012, representing the 4th rank for incidence and the 1st rank for mortality [2]. Data from

\footnotetext{
* Correspondence: aseigneurin@chu-grenoble.fr

${ }^{1}$ Isère Cancer Registry, CHU Grenoble, Grenoble, France

${ }^{2}$ Grenoble Alpes University, Techniques de I'Ingénierie Médicale et de la Complexité - Informatique Mathématiques et Applications Grenoble, Unité Mixte de Recherche 5525, Grenoble, France

Full list of author information is available at the end of the article
}

cancer registries contributing to the International Agency for Research on Cancer (IARC) database showed that lung cancer incidence rates have peaked among men in many areas of the world, whereas rates among women continue to rise [3].

The prognosis of lung cancer remains poor and the improvement in survival that have been realized in other cancers have yet to be achieved in lung cancer. Indeed, the 5-year relative survival rate in US cancer registries for lung cancer diagnosed in 2008-2014 was $18.6 \%$ [4]. In France, the 5-year net survival rate for lung cancer diagnosed in $2005-2010$ was $17 \%$ (95\% CI: $16-17 \%$ ) and the 10 -year net survival was only $10 \%$ for the diagnoses

(c) The Author(s). 2018 Open Access This article is distributed under the terms of the Creative Commons Attribution 4.0 International License (http://creativecommons.org/licenses/by/4.0/), which permits unrestricted use, distribution, and reproduction in any medium, provided you give appropriate credit to the original author(s) and the source, provide a link to the Creative Commons license, and indicate if changes were made. The Creative Commons Public Domain Dedication waiver (http://creativecommons.org/publicdomain/zero/1.0/) applies to the data made available in this article, unless otherwise stated. 
in the 1999-2004 period [5]. Several prognostic factors for non-small cell cancers have been identified [6, 7]. Stage at diagnosis remains one of the main factor [8] and other potential prognostic factors include performance status $[9,10]$, increasing age $[10,11]$, male gender [12] and low socio economic status, [11] whereas the histological sub-type of non-small cell cancer remains controversial $[13,14]$. For small cell cancers, disease extent and performance status were identified as independent prognostic factors [15].

The association of comorbidity based on the Charlson Comorbidity Index (CCI) with lung cancer prognosis remains discussed. Compared to an absence of comorbidity, lower survival was found for CCI grades $1-2$ and $\geq 3$ among non-small cell cancers who underwent curative surgery [10]. An analysis of a Spanish hospital database that included all histological types of lung cancers showed an impaired prognosis only for CCI grades $\geq 3$ [16]. CCI grades 1-2 and $\geq 3$ were associated with lower survival rates only for patients diagnosed with a low stage lung cancer (staged as 1 or 2) in a population-based study from the Danish Lung Cancer Registry [17]. On the other hand, Ganti et al. [18] did not find differences in survival for different CCI grades among all histological types of lung cancer treated in a US hospital. Few studies were conducted to estimate the association of CCI with long term survival rates using population-based data, separately for each histological type.

The objective of this study was to assess if CCI was associated with 8-year survival using population-based data, separately for adenocarcinomas, squamous cell carcinomas and small cell cancers.

\section{Methods}

\section{Study design and setting}

A retrospective cohort study was conducted using cases recruited from cancer registries. The original data from 9 cancer registries of the French network of cancer registries (FRANCIM) which covered 10 French administrative entities (Départements of Calvados, Doubs, Hérault, Isère, Loire-Atlantique, Manche, Bas-Rhin, Somme, Tarn, Vendée) were analysed.

\section{Participants}

Participants were randomly selected from the databases of cancer registries on the basis of the day and month of birth of patients.

The total number of cases included in the analysis was computed considering the comparison of survival rates between two groups using the Log rank test. The primary objective was to assess if CCI was associated with 8 -year survival among each histological type of lung cancer. Considering 4 groups of CCI grades, a total of 67 cases per group corresponding to 268 cases per histological type was necessary to detect a Hazard Ratio of 0.6 with a 8-year survival rate of $10 \%$ in the reference group, a $80 \%$ statistical power and a $5 \%$ alpha threshold. In a previous study, small cell cancer was the less frequent histological group representing between 12 and 18\% of all lung cancers, depending on period of diagnosis and sex [19]. Consequently, the necessary number of lung cancers in the study was 1787 to obtain at least 268 cases of small cell cancers (268/0.15). As a result, the objective was to include 1800 cases corresponding to 200 cases for each cancer registry.

Inclusion criteria were as follows: invasive lung cancers classified as C34 in the International Classification of Disease for Oncology - 3 [20], diagnosed in 2004 among individuals who lived in one of the 10 administrative entities covered by the cancer registries. Only adenocarcinomas, squamous cell cancers and small cell cancers were considered for the analysis since other histological types were less frequent and constituted an heterogeneous group.

\section{Data collection}

Cancer registries routinely collected lung cancer cases from different sources including histopathology laboratories, oncology departments, multidisciplinary meetings, and computerized hospital discharge databases. For this specific study, a supplementary collection of data in medical files was carried out to follow-up participants and to collect diagnostic mode, tobacco smoking, comorbidity, stage at diagnosis and treatment. Specific training sessions were implemented to provide a consistent collection of data among the cancer registries.

Stage for small-cell cancers was defined as limited (cancer remaining in one side of the chest including lung and lymph nodes on the same side of the chest) or extensive (cancer spreading widely throughout the lung, to the other lung, to lymph nodes on the other side of the chest, or to distant organs). Non-small cell cancers were categorized according to the TNM staging system [21] as stage 1 (T1-T2 N0 M0), stage 2 (T1-T2 N1 M0; T3 N0 M0), stage 3 (T1-T2-T3 N2 M0; T3 N1 M0; T1-T2-T3-T4 N3 M0; T4 N0-N1-N2-N3 M0) and stage 4 (T1-T2-T3-T4 N0-N1-N2-N3 M1).

The presence of comorbidities was collected using the Charlson Comorbidity Index (CCI) [22]. Briefly, the CCI is a simple and valid method of classifying comorbidity based on a weighted index that takes into account the number and the seriousness of comorbid condition. We collected data on the presence of comorbid condition at the time of diagnosis from hospitals and GP's medical files. Performance status was not included considering the important proportion of missing values in medical files.

An active search for the vital status at June 30, 2013 was carried out for all cases included in the study. The 
information was collected for individuals with a birthplace known by an electronic request to the Répertoire National d'Identification des Personnes Physiques which collects data on deaths in France. In case of missing birthplace, other sources of information on the vital status were used such as medical records.

\section{Study outcomes}

The main study endpoint was all cause of death during a 8-year follow-up period.

\section{Statistical analyses}

Observed and net survival rates, i.e. survival rates that would have been observed if lung cancer was the only cause of death in the population, were computed by histological type and CCI grades. Observed survival rates were obtained using the Kaplan-Meier method. Considering the unavailability and unreliability of causes of deaths, net survival rates were computed using the Pohar-Perme estimator of the net cumulative rate which did not require knowing causes of deaths [23]. Indeed, lung cancer mortality was deduced from the all-cause mortality of the study group and the "expected" mortality of a disease-free group. This expected mortality was assumed to reflect correctly the mortality due to other causes than lung cancer and was obtained from the general population life tables [24].

Three Cox models were independently built for adenocarcinomas, squamous cell cancers and small cell cancers to estimate the adjusted hazard ratio of death for different CCI grades. The proportional-hazards assumption was assessed graphically and tested on the basis of Schoenfeld residuals. Time-varying variables were introduced if the proportional hazard assumption was not met to estimate different effects during the $0-1$ year and 1-8 years period after diagnosis. For each histological type, a full model was considered including sex, age group, CCI, stage, and diagnostic mode since asymptomatic cancers could be associated with better survival rates due to lead time, length bias and overdiagnosis.

\section{Results}

A total of 1751 lung cancer cases diagnosed in 2004 were collected. Adenocarcinoma was the most frequent histological type (36.9\%), followed by squamous cell carcinoma (29.9\%) and small cell carcinomas (13.3\%). Other histological types represented $15.6 \%$ of cases and $4.2 \%$ had no cytological or histological diagnosis. Observed and net 8-year survival rates for all histological groups and stages combined were 9.7\% (95\% CI: 8.4-11.2\%) and 11.2\% (95\% CI: 9.5-12.8\%), respectively.

The present study focused on adenocarcinomas, squamous cell and small cell cancers. The main characteristics of the participants are summarized in Table 1 . The repartition of gender differed by histological type: the proportion of men was $68.1 \%$ for adenocarcinomas, 90.5\% for squamous cell cancers and $82.0 \%$ for small cell cancers. For each histological type, the upper lobe was the most frequent topography and pulmonary symptom was the most frequent diagnostic mode. The most frequent comorbid conditions were similar for the three histological types of lung cancers considered with chronic obstructive pulmonary disease, followed by peripheral vascular disease, and congestive heart failure. By June 30,2013 , less than $1.5 \%$ of individuals were lost to follow-up (Table 2).

Net 8-year survival rates, reported in Table 2, remained low for each histological group: 12.6\% (95\% CI: 9.8$15.4 \%$ ) for adenocarcinomas, $13.4 \%$ (95\% CI: 10.1-16.7\%) for squamous cell cancers and 3.7\% (95\% CI: 1.1-6.3\%) for small cell cancers. Observed and net survival rates were close for all histological types.

Observed and net survival rates decreased when the CCI grade was $\geq 3$ for all histological group (Table 3 ). Univariate and multivariate prognostic factors obtained from Cox models are reported in Table 4. After adjustment for sex, age group, stage and diagnostic mode, CCI grades 1, 2 and $\geq 3$ were associated with lower survival rates only for small cell cancers, whereas no differences were observed for adenocarcinomas and squamous cell cancers. Stage at diagnosis remains the main prognostic factor for all histological types. Females were associated with higher survival rates only for adenocarcinomas and age at diagnosis $\geq 80$ was associated with lower survival rates for the 3 histological types. We did not include variables related to treatments in our model due to a high level of collinearity with stage. The proportion of patients who did not receive any curative treatments for CCI grades $0,1,2$ and $\geq 3$ were 10.3, 13.1, 16.1 and $29.2 \%$ for small cell cancers, 11.9, 11.9, 11.9 and $16.1 \%$ for adenocarcinomas, 12.3, 15.3, 20.2 and $21.3 \%$ for squamous cell cancers, respectively.

\section{Discussion}

Eight-year net survival rates remained low for all histological types of lung cancers and CCI grades, ranging from $0.0 \%$ (95\% CI: $0.0-1.0 \%)$ for individuals with a CCI grade $\geq 3$ diagnosed with a small-cell carcinoma, to 14.1\% (95\% CI: $8.7-19.4 \%$ ) for individuals with a CCI grade 0 diagnosed with a squamous cell carcinoma. We found lower survival rates for individuals with $\mathrm{CCI}$ grades 1,2 and $\geq 3$ compared to individuals without comorbidity only for small cell cancers, after adjustment for sex, age group, stage and diagnostic mode.

The main patient and cancer characteristics by histological types are consistent with data from literature, including the high proportion of men among squamous cell lung cancers $[25,26]$. Since squamous cell cancer is 
Table 1 Characteristics of the 1403 individuals diagnosed with lung cancers in 2004 categorized as adenocarcinomas, squamous cell carcinomas and small cell cancers and recruited among 10 French cancer registries

\begin{tabular}{|c|c|c|c|}
\hline & Adenocarcinomas & Squamous cell carcinomas & Small cell carcinomas \\
\hline & $N=646(100.0 \%)$ & $N=524(100.0 \%)$ & $N=233(100.0 \%)$ \\
\hline \multicolumn{4}{|l|}{ Sex } \\
\hline Male & $440(68.1 \%)$ & $474(90.5 \%)$ & $191(82.0 \%)$ \\
\hline Female & $206(31.9 \%)$ & $50(9.5 \%)$ & $42(18.0 \%)$ \\
\hline \multicolumn{4}{|l|}{ Age group } \\
\hline$<50$ & $89(13.8 \%)$ & $21(4.0 \%)$ & $19(8.1 \%)$ \\
\hline $50-59$ & $186(28.8 \%)$ & $118(22.5 \%)$ & $68(29.2 \%)$ \\
\hline $60-69$ & $162(25.1 \%)$ & $142(27.1 \%)$ & $57(24.5 \%)$ \\
\hline $70-79$ & $163(25.2 \%)$ & $173(33.0 \%)$ & $70(30.0 \%)$ \\
\hline$\geq 80$ & $46(7.1 \%)$ & $70(13.4 \%)$ & 19 (8.1\%) \\
\hline \multicolumn{4}{|l|}{ Comorbid conditions $^{a}$} \\
\hline Chronic obstructive pulmonary disease & $130(20.1 \%)$ & $161(30.7 \%)$ & $54(23.2 \%)$ \\
\hline Peripheral vascular disease & $86(13.3 \%)$ & $77(14.7 \%)$ & $28(12.0 \%)$ \\
\hline Congestive heart failure & $54(8.4 \%)$ & $75(14.3 \%)$ & $23(9.9 \%)$ \\
\hline \multicolumn{4}{|l|}{ Charlson Comorbidity Index } \\
\hline 0 & 319 (49.4\%) & 195 (37.2\%) & 107 (45.9\%) \\
\hline 1 & $159(24.6 \%)$ & 157 (30.0\%) & $61(26.2 \%)$ \\
\hline 2 & $84(13.0 \%)$ & 79 (15.1\%) & $31(13.3 \%)$ \\
\hline$\geq 3$ & $62(9.6 \%)$ & $75(14.3 \%)$ & $24(10.3 \%)$ \\
\hline Unknown & $22(3.4 \%)$ & $18(3.4 \%)$ & $10(4.3 \%)$ \\
\hline \multicolumn{4}{|l|}{ Topography } \\
\hline Main bronchus & $22(3.4 \%)$ & $59(11.3 \%)$ & $24(10.3 \%)$ \\
\hline Upper lobe & $341(52.8 \%)$ & $254(48.5 \%)$ & 109 (46.8\%) \\
\hline Middle lobe & $26(4.0 \%)$ & $14(2.7 \%)$ & $12(5.1 \%)$ \\
\hline Lower lobe & $153(23.7 \%)$ & $133(25.4 \%)$ & $43(18.5 \%)$ \\
\hline Overlapping lesion & $33(5.1 \%)$ & $25(4.8 \%)$ & $26(11.2 \%)$ \\
\hline Not specified & $71(11.0 \%)$ & $39(7.4 \%)$ & 19 (8.1\%) \\
\hline \multicolumn{4}{|l|}{ Stage } \\
\hline \multicolumn{4}{|l|}{ Non-small cell - Surgery } \\
\hline 1 & $75(41.0 \%)$ & $52(37.4 \%)$ & - \\
\hline 2 & $18(9.8 \%)$ & $39(28.1 \%)$ & - \\
\hline 3 & $62(33.9 \%)$ & $45(32.4 \%)$ & - \\
\hline 4 & $26(14.2 \%)$ & $2(1.4 \%)$ & - \\
\hline Unknown & $2(1.1 \%)$ & $1(0.7 \%)$ & - \\
\hline \multicolumn{4}{|l|}{ Non-small cell - No surgery } \\
\hline 1 & $8(1.7 \%)$ & $16(4.2 \%)$ & - \\
\hline 2 & $2(0.4 \%)$ & $5(1.3 \%)$ & - \\
\hline 3 & $87(18.8 \%)$ & $138(36.0 \%)$ & - \\
\hline 4 & $354(76.5 \%)$ & $198(51.7 \%)$ & - \\
\hline Unknown & $12(2.6 \%)$ & $26(6.8 \%)$ & - \\
\hline
\end{tabular}


Table 1 Characteristics of the 1403 individuals diagnosed with lung cancers in 2004 categorized as adenocarcinomas, squamous cell carcinomas and small cell cancers and recruited among 10 French cancer registries (Continued)

\begin{tabular}{|c|c|c|c|}
\hline & $\begin{array}{l}\text { Adenocarcinomas } \\
N=646(100.0 \%)\end{array}$ & $\begin{array}{l}\text { Squamous cell carcinomas } \\
N=524(100.0 \%)\end{array}$ & $\begin{array}{l}\text { Small cell carcinomas } \\
N=233(100.0 \%)\end{array}$ \\
\hline \multicolumn{4}{|l|}{ Small cell - Surgery } \\
\hline Limited & - & - & $6(85.7 \%)$ \\
\hline Extensive & - & - & $1(14.3 \%)$ \\
\hline Unknown & - & - & $0(0.0 \%)$ \\
\hline \multicolumn{4}{|l|}{ Small cell - No surgery } \\
\hline Limited & - & - & $61(27.1 \%)$ \\
\hline Extensive & - & - & $155(68.9 \%)$ \\
\hline Unknown & - & - & $9(4.0 \%)$ \\
\hline \multicolumn{4}{|l|}{ Diagnostic mode } \\
\hline Incidental diagnosis & $76(11.8 \%)$ & $57(10.9 \%)$ & $19(8.1 \%)$ \\
\hline Pulmonary symptoms & $360(55.7 \%)$ & $350(66.8 \%)$ & $143(61.4 \%)$ \\
\hline Other symptoms & $169(26.2 \%)$ & $96(18.3 \%)$ & $63(27.0 \%)$ \\
\hline Surveillance of high-risk patients & $29(4.5 \%)$ & $12(2.3 \%)$ & $2(0.9 \%)$ \\
\hline Unknown & $12(1.9 \%)$ & $9(1.7 \%)$ & $6(2.6 \%)$ \\
\hline \multicolumn{4}{|l|}{ Tobacco smoking } \\
\hline Current smoker & $274(42.4 \%)$ & $224(42.7 \%)$ & $123(52.8 \%)$ \\
\hline Former-smoker & $227(35.1 \%)$ & $248(47.3 \%)$ & 89 (38.2\%) \\
\hline Never smoker & $85(13.2 \%)$ & $15(2.9 \%)$ & $1(0.4 \%)$ \\
\hline Unknown & $60(9.3 \%)$ & $37(7.1 \%)$ & $20(8.6 \%)$ \\
\hline \multicolumn{4}{|l|}{ Absence of treatment } \\
\hline Yes & $78(12.1 \%)$ & $84(16.0 \%)$ & $34(14.6 \%)$ \\
\hline Unknown & $0(0.0 \%)$ & 0 (0.0\%) & 0 (0.0\%) \\
\hline
\end{tabular}

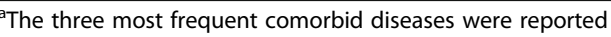

Table 2 Observed and net survival rates (\% (95\% CI)) by histological types among lung cancers diagnosed in 2004 and recruited in 10 French cancer registries

\begin{tabular}{llll}
\hline & $\begin{array}{l}\text { Adenocarcinoma } \\
N=646\end{array}$ & $\begin{array}{l}\text { Squamous cell carcinoma } \\
N=524\end{array}$ & $\begin{array}{c}\text { Small cell carcinoma } \\
N=233\end{array}$ \\
\hline $\begin{array}{lll}\text { Number of person-years } \\
\text { Percentage of dead within 8 years }\end{array}$ & 1374.5 & 1020.7 & 264.8 \\
Lost to follow-up at 8 years & $88.5 \%$ & $88.7 \%$ & $96.6 \%$ \\
$\begin{array}{l}\text { 1-year survival rate } \\
\text { Observed }\end{array}$ & $1.4 \%$ & $1.3 \%$ & $0.4 \%$ \\
Net & $49.4 \%(45.5-53.2 \%)$ & $43.3 \%(39.0-47.5 \%)$ & $31.8 \%(25.9-37.8 \%)$ \\
5-year survival rate & $50.1 \%(46.2-54.0 \%)$ & $44.5 \%(40.1-48.8 \%)$ & $32.2 \%(26.2-38.3 \%)$ \\
$\quad$ Observed & $15.8 \%(13.1-18.8 \%)$ & & $3.9 \%(1.9-6.9 \%)$ \\
$\quad$ Net & $17.1 \%(14.1-20.2 \%)$ & $14.9 \%(12.0-18.1 \%)$ & $4.1 \%(1.6-6.7 \%)$ \\
8-year survival rate & & $16.5 \%(13.1-19.9 \%)$ & $3.4 \%(1.6-6.4 \%)$ \\
$\quad$ Observed & $11.2 \%(8.9-13.8 \%)$ & $11.2 \%(8.7-14.1 \%)$ & $3.7 \%(1.1-6.3 \%)$ \\
$\quad$ Net & $12.6 \%(9.8-15.4 \%)$ & $13.4 \%(10.1-16.7 \%)$ & \\
\hline
\end{tabular}


Table 3 Observed and net 8-year survival rates (\% (95\% CI)) by histological type and Charlson Comorbidity Index (CCI) grade for adenocarcinomas, squamous cell carcinomas and small cell cancers diagnosed in 2004 and recruited among 10 French cancer registries

\begin{tabular}{|c|c|c|c|c|c|c|}
\hline \multirow{2}{*}{$\begin{array}{l}\mathrm{CCl} \\
\text { grade }\end{array}$} & \multicolumn{2}{|c|}{ Adenocarcinomas $(n=646)$} & \multicolumn{2}{|c|}{ Squamous cell cancers $(n=524)$} & \multicolumn{2}{|c|}{ Small cell cancers $(n=233)$} \\
\hline & Observed survival & Net survival & Observed survival & Net survival & Observed survival & Net survival \\
\hline 0 & $12.3 \%(9.0-16.2 \%)$ & $13.7 \%(9.7-17.8 \%)$ & $12.3 \%(8.2-17.3 \%)$ & $14.1 \%(8.7-19.4 \%)$ & $3.7 \%(1.2-8.6 \%)$ & $4.1 \%(0.2-8.0 \%)$ \\
\hline 1 & $13.2 \%(8.5-19.0 \%)$ & $15.1 \%(9.1-22.2 \%)$ & $10.2 \%(6.1-15.5 \%)$ & $12.6 \%(6.8-18.4 \%)$ & $3.3 \%(0.6-10.1 \%)$ & $3.5 \%(0.0-7.8 \%)$ \\
\hline 2 & $11.9 \%(6.1-19.8 \%)$ & $14.0 \%(5.7-22.2 \%)$ & $13.7 \%(7.2-22.3 \%)$ & $17.4 \%(7.9-26.8 \%)$ & $3.2 \%(0.2-14.1 \%)$ & $3.3 \%(0.0-8.4 \%)$ \\
\hline$\geq 3$ & $1.6 \%(0.1-7.6 \%)$ & $1.7 \%(0.0-4.5 \%)$ & $8.0 \%(3.3-15.5 \%)$ & $10.1 \%(2.3-17.9 \%)$ & $0.0 \%(0.0-0.0 \%)$ & $0.0 \%(0.0-1.0 \%)$ \\
\hline
\end{tabular}

one of the histological types the most closely associated with smoking, the higher smoking rate among men could explain this finding.

Several hypotheses can be considered to explain the lower survival rates observed for patients with comorbidities. First, the presence of comorbidities could increase the delay of diagnosis of lung cancer implying a worst prognosis. We partly took into account the delay of diagnosis by including stage at diagnosis and diagnostic mode in our analyses but a residual effect could still be observed. Second, the use of sub optimal treatments when CCI grades increased could result in an increase of lung cancer-related deaths. For small cell cancers, the decrease of net survival rates from $3.3 \%$ for patients with CCI grade 2 to $0.0 \%$ for CCI grade $\geq 3$ is consistent with this explanation, as well as the increase with CCI grades of the proportion of patients receiving no curative treatments. Less extensive treatments due to the presence of comorbid conditions could also be an explanation for the impaired survival rates. However, the precise type of treatment was not available in our database to verify this hypothesis. Søgaard et al. in a literature review found that patients with comorbidities were less likely to receive guideline-recommended treatments [27]. Third, lung cancer and its treatment could imply a sub optimal treatment of an active comorbidity as well as an unfavorable evolution of the comorbid condition, resulting in an increase of comorbidity-related deaths. Finally, differences in survival rates by CCI grade could reflect differences in socio-economic status [27] but this information was not available at an individual level in our study.

We found an association between the CCI grade at diagnosis and 8-year survival rates only for small cell cancers. The reason for this finding remains unclear. An increased delay of diagnosis, sub optimal treatments for the cancer and/or the comorbid condition and differences in socio-economic status could be observed more frequently for small cell cancers. Moreover, the effect on mortality of these factors might be more important for small cell lung cancer due to specificities in the natural history, the prognosis and the types of treatment performed compared to non-small cell cancers. In the literature, several authors also found lower survival rates for increasing CCI grades for adenocarcinomas and squamous cell cancers when the analysis was restricted to sub groups of patients. Birim et al. [10] studied resected non-small cell lung cancers performed in an hospital and found that after adjusting for several confounders including age, sex, stage and individual comorbid conditions, survival was lower among patients with CCI grades $1-2$ and $\geq 3$ compared to patients with no comorbidity. A Danish population-based study found that CCI grade $\geq 3$ was associated with lower survival among resected non-small lung cell cancers [28]. Few articles studied the effect of CCI grades on survival rates for small cell cancers. Dalton et al. [17] found that CCI grades 1-2 and $\geq 3$ were associated with impaired survival only among lung cancers categorized as stage 1 and 2 in an analysis that included both small cell and non-small cell cancers.

Many studies reported prognostic factors of lung cancer $[7,29,30]$. Several studies reported an effect of sex on prognosis whereas we identified a better prognosis for women only among adenocarcinomas. The Surveillance, Epidemiology, and End Results database from 1975 to 1999 showed lower survival for men based on separate analyses by stage at diagnosis and after adjustment for histological type, treatment and age [12]. For small cell cancers, individual data pooled from first-line treatment trials showed a lower survival for men after adjustment for confounding factors [29]. On the other hand, no sex difference was found for resected nonsmall cell cancers diagnosed in the Medical University of Innsbruck, Austria [31]. Consistent with our results, several studies found lower survival rates for older patients [12, 29, 32].

The limits of our study should be acknowledged. First, the statistical power might have been too low to identify small effects on survival. Second, we could not exclude misclassification of the CCI related to differences in recording comorbidities in medical files [22]. Moreover, we considered comorbidities at the time of diagnosis in our analyses and we did not take into account the diagnosis of comorbid condition during the follow-up. The frequency of comorbidities increases with age, especially among the age group studied, and this increase of 


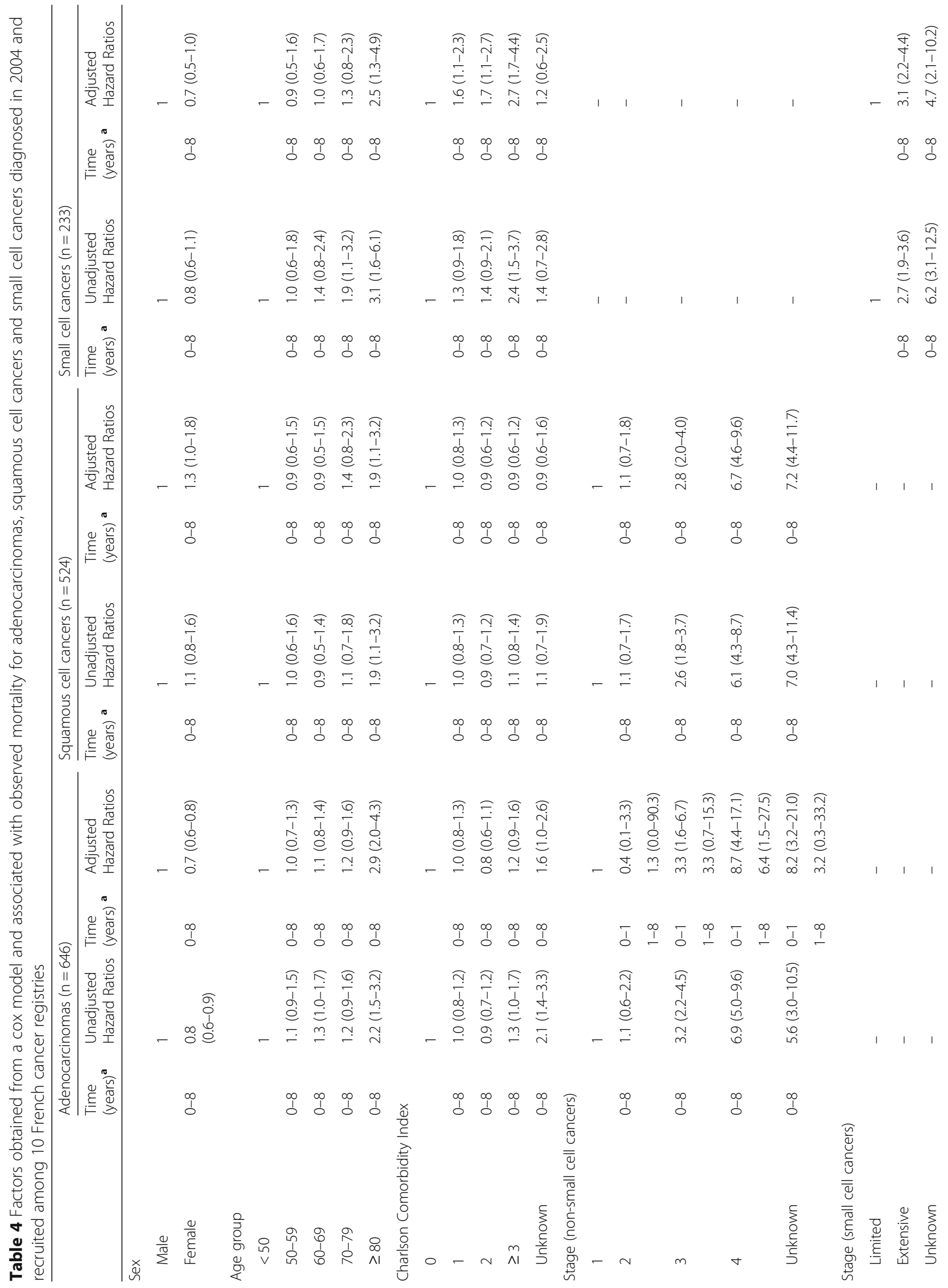




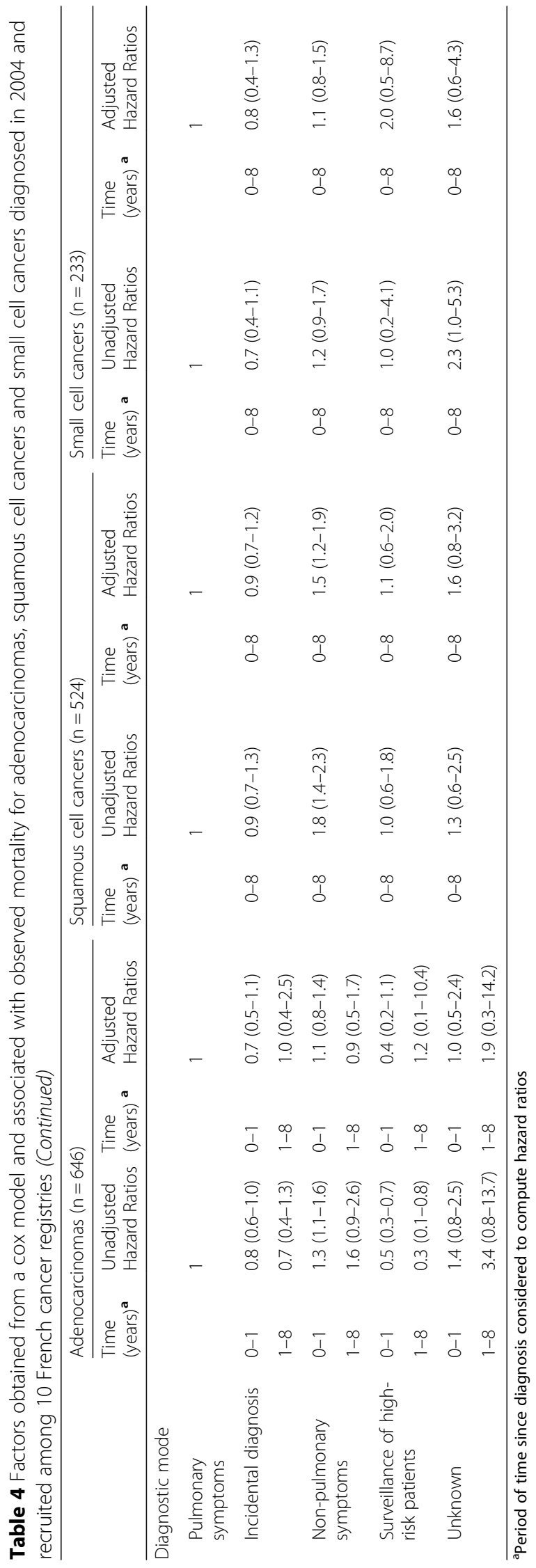


comorbidities could affect mortality. Third, we could not collect the cause of death and the multivariate analysis was based on all-cause mortality. As a result, we could not distinguish the effect of comorbidity on lung cancer deaths and comorbidity-related deaths. Fourth, performance status was not introduced as a prognostic factor in our model since this information was not fully available in medical files. Finally, staging procedures have changed since 2004 including the widespread use of PET scan. However, the main objective was to assess the impact of comorbidities on survival adjusted for other prognosis factors. Stage was only used for adjustment purposes and the estimation of its precise effect on survival was not our main objective.

Our study present several strengths. First, we used population-based data from 10 cancer registries resulting in the absence of selection bias encountered in studies based on data obtained in specialized centres or randomized trials. Differences of cancer characteristics and practice patterns may exist among centres but the study reflects diagnosis of lung cancers and treatments in the general population. Second, we estimated the association of CCI grade and survival considering a long follow-up of 8 years. Third, the proportion of individuals lost to follow-up was low. Finally, we analysed the effect of CCI grades on survival separately for adenocarcinomas, squamous cell cancers and small cell cancers.

\section{Conclusion}

After adjustment for age, sex, stage and diagnostic mode, the presence of comorbidity based on CCI grades 1-2 and $\geq 3$ was associated with lower 8 -year survival rates for small cell cancers whereas no differences were found for adenocarcinomas and squamous cell cancers. Further studies should be conducted to assess differences of survival by CCI grades among sub groups of adenocarcinomas and squamous cell cancers and to elucidate the mechanisms explaining the lower survival associated with comorbid conditions among small cell lung cancers.

\section{Acknowledgments}

The authors thank the French Assurance Maladie and all participant cancer centres, hospitals, private clinics, and pathologists for case identification and data collection.

\section{Funding}

This work was supported by the Institut National du Cancer, Paris, France [grant number 0612-3D1514-14], and by the Ligue Nationale contre le Cancer, Paris, France. Funding bodies had no role in the design of the study, collection, analysis, and interpretation of data and in writing the manuscript.

\section{Availability of data and materials}

Data will not be shared since the datasets analyzed included identifying patient data.

\section{Authors' contributions}

$A S, P D$ and $M C$ designed the study and analyzed the data. AS wrote the manuscript and PD, BT, ASW, MV, PG, AVG, BLL, SB, FM, MC contributed to writing of the manuscript. All authors read and approved the final manuscript.

\section{Ethics approval and consent to participate}

This study is based on data from cancer registries gathered in the French network of cancer registries and a representative of each registry was involved in the study and approved the use of its data. Ethics approval and consent to participate were not required for this study.

\section{Consent for publication}

Not applicable

\section{Competing interests}

The authors declare that they have no competing interests.

\section{Publisher's Note}

Springer Nature remains neutral with regard to jurisdictional claims in published maps and institutional affiliations.

\section{Author details}

${ }^{1}$ Isère Cancer Registry, CHU Grenoble, Grenoble, France. ${ }^{2}$ Grenoble Alpes University, Techniques de l'Ingénierie Médicale et de la Complexité Informatique Mathématiques et Applications Grenoble, Unité Mixte de Recherche 5525, Grenoble, France. ${ }^{3}$ Medical evaluation unit, CHU Grenoble Alpes, Grenoble, France. ${ }^{4}$ Hérault Cancer Registry, Montpellier, France. ${ }^{5}$ Doubs Cancer Registry, CHU Besançon, Besançon, France. ${ }^{6}$ Bas-Rhin Cancer Registry, Université de Strasbourg, Strasbourg, France. ${ }^{7}$ Tarn Cancer Registry, Institut Claudius Regaud, IUCT-O, Registre des cancer du Tarn, Toulouse, France. ${ }^{8}$ LEASP - UMR 1027 Inserm-Université Toulouse III, Toulouse, France. ${ }^{9}$ Calvados Cancer Registry, CLCC François Baclesse, Caen, France. ${ }^{10}$ Somme Cancer Registry, CHU Amiens, Amiens, France. ${ }^{11}$ Manche Cancer Registry, $\mathrm{CH}$ du Cotentin, Cherbourg en Cotentin, France. ${ }^{12}$ Loire-Atlantique and Vendée Cancer Registry, CHU Nantes, Nantes, France.

Received: 7 September 2017 Accepted: 28 October 2018 Published online: 12 November 2018

References

1. Ferlay J, Soerjomataram I, Dikshit R, Eser S, Mathers C, Rebelo M, Parkin DM, Forman D, Bray F. Cancer incidence and mortality worldwide: sources, methods and major patterns in GLOBOCAN 2012. Int J Cancer. 2015;136:E359-86.

2. Binder-Foucard F, Bossard N, Delafosse P, Belot A, Woronoff A-S, Remontet $L$. French network of cancer registries (Francim). Cancer incidence and mortality in France over the 1980-2012 period: solid tumors. Rev D'épidémiologie Santé Publique. 2014;62:95-108.

3. Devesa SS, Bray F, Vizcaino AP, Parkin DM. International lung cancer trends by histologic type: male:female differences diminishing and adenocarcinoma rates rising. Int J Cancer. 2005;117:294-9.

4. Howlader N, Noone A, Krapcho M, Garshell J, Miller D, Altekruse S, Kosary C, Yu M, Ruhl J, Tatalovich Z, Mariotto A, Lewis D, Chen H, Feuer E, Cronin K. SEER Cancer Statistics Review, 1975-2012 [Internet]. National Cancer Institute. Bethesda, MD; 2015 [cited 2016 Jan 22]. Available from: https://seer.cancer.gov/statfacts/html/lungb.html.

5. Cowppli-Bony A, Uhry Z, Remontet L, Guizard AV, Voirin N, Monnereau A, Bouvier A-M, Colonna M, Bossard N, Woronoff A-S, Grosclaude P. Survie des personnes atteintes de cancer en France métropolitaine 1989-2013. Étude à partir des registres des cancers du réseau Francim Partie 1 - Tumeurs solides. Saint Maurice: Institut de Veille Sanitaire; 2016.

6. Brundage MD, Davies D, Mackillop WJ. Prognostic factors in non-small cell lung cancer: a decade of progress. Chest. 2002;122:1037-57.

7. Solan MJ, Werner-Wasik M. Prognostic factors in non-small cell lung cancer. Semin Surg Oncol. 2003;21:64-73.

8. Surveillance, Epidemiology, and End Results Program. SEER Stat Fact Sheets: Lung and Bronchus Cancer. 5-Year Relative Survival by Stage at Diagnosis. http://seer.cancer.gov/statfacts/html/lungb.html Date last accessed: 4 Jul 2018.

9. Firat S, Bousamra M, Gore E, Byhardt RW. Comorbidity and KPS are independent prognostic factors in stage I non-small-cell lung cancer. Int J Radiat Oncol Biol Phys. 2002;52:1047-57.

10. Birim O, Kappetein AP, Bogers AJJC. Charlson comorbidity index as a predictor of long-term outcome after surgery for nonsmall cell lung cancer. Eur J Cardiothorac Surg. 2005;28:759-62. 
11. S-HI O, Zell JA, Ziogas A, Anton-Culver H. Prognostic factors for survival of stage I nonsmall cell lung cancer patients : a population-based analysis of 19,702 stage I patients in the California Cancer registry from 1989 to 2003. Cancer. 2007:110:1532-41.

12. Fu JB, Kau TY, Severson RK, Kalemkerian GP. Lung cancer in women: analysis of the national surveillance, epidemiology, and End Results database. Chest. 2005;127:768-77.

13. Salmerón D, Chirlaque MD, Isabel Izarzugaza M, Sánchez MJ, Marcos-Gragera R, Ardanaz E, Galceran J, Mateos A, Navarro C. Lung cancer prognosis in Spain: the role of histology, age and sex. Respir Med. 2012;106:1301-8.

14. Nilssen Y, Strand TE, Fjellbirkeland L, Bartnes K, Møller B. Lung cancer survival in Norway, 1997-2011: from nihilism to optimism. Eur Respir J. 2016; 47:275-87.

15. Li J, Dai C-H, Chen P, Wu J-N, Bao Q-L, Qiu H, Li X-Q. Survival and prognostic factors in small cell lung cancer. Med Oncol. 2010;27:73-81.

16. Parés-Badell O, Banqué M, Macià F, Castells X, Sala M. Impact of comorbidity on survival by tumour location: breast, colorectal and lung cancer (2000-2014). Cancer Epidemiol. 2017;49:66-74.

17. Dalton SO, Steding-Jessen M, Jakobsen E, Mellemgaard A, Østerlind K, SchüZ J, Johansen C. Socioeconomic position and survival after lung cancer: influence of stage, treatment and comorbidity among Danish patients with lung cancer diagnosed in 2004-2010. Acta Oncol. 2015;54:797-804.

18. Ganti AK, Siedlik E, Marr AS, Loberiza FR, Kessinger A. Predictive ability of Charlson comorbidity index on outcomes from lung cancer. Am J Clin Oncol. 2011;34:593-6.

19. Molinié F, Velten M, Remontet L, Bercelli P. Réseau Francim null. [the progression of lung cancer incidence in France (1978-2000)]. Rev Mal Respir. 2006;23:127-34

20. Fritz A, Percy C, Jack A, Shanmugaratnam K, Sobin L, Parkin DM, Whelan S. International Classification of Diseases for oncology. 3rd ed. Geneva: World Health Organization; 2008.

21. Sobin $L$, Wittekind $C$. The TNM classification of malignant tumors. Sixth edition. 2002.

22. Charlson ME, Pompei P, Ales KL, MacKenzie CR. A new method of classifying prognostic comorbidity in longitudinal studies: development and validation. J Chronic Dis. 1987;40:373-83.

23. Perme MP, Stare J, Estève J. On estimation in relative survival. Biometrics, 2012;68:113-20.

24. Roche L, Danieli C, Belot A, Grosclaude P, Bouvier A-M, Velten M, Iwaz J, Remontet L, Bossard N. Cancer net survival on registry data: use of the new unbiased Pohar-Perme estimator and magnitude of the bias with the classical methods. Int J Cancer. 2013;132:2359-69.

25. Foeglé J, Hédelin G, Lebitasy M-P, Purohit A, Velten M, Quoix E. Specific features of non-small cell lung cancer in women: a retrospective study of 1738 cases diagnosed in bas-Rhin between 1982 and 1997. J Thorac Oncol. 2007;:2:466-74

26. Zhang $X$, Wu L, Xu Y, Zhang B, Wu X, Wang Y, Pang Z. Trends in the incidence rate of lung cancer by histological type and gender in Sichuan, China, 19952015: a single-center retrospective study. Thorac Cancer. 2018;9:532-41.

27. Søgaard M, Thomsen RW, Bossen KS, Sørensen HT, Nørgaard M. The impact of comorbidity on cancer survival: a review. Clin Epidemiol. 2013;5:3-29.

28. Lüchtenborg M, Jakobsen E, Krasnik M, Linklater KM, Mellemgaard A, Møller $H$. The effect of comorbidity on stage-specific survival in resected non-small cell lung cancer patients. Eur J Cancer. 2012;48:3386-95.

29. Foster NR, Mandrekar SJ, Schild SE, Nelson GD, Rowland KM, Deming RL, Kozelsky TF, Marks RS, Jett JR, Adjei AA. Prognostic factors differ by tumor stage for small cell lung cancer: a pooled analysis of north central Cancer treatment group trials. Cancer. 2009;115:2721-31.

30. Mangone L, Minicozzi P, Vicentini M, Giacomin A, Caldarella A, Cirilli C Falcini F, Giorgi Rossi P, Sant M. Key factors influencing lung cancer survival in northern Italy. Cancer Epidemiol. 2013;37:226-32.

31. Sterlacci W, Tzankov A, Veits L, Oberaigner W, Schmid T, Hilbe W, Fiegl M. The prognostic impact of sex on surgically resected non-small cell lung cancer depends on clinicopathologic characteristics. Am J Clin Pathol. 2011;135:611-8.

32. Moore R, Doherty D, Chamberlain R, Khuri F. Sex differences in survival in non-small cell lung cancer patients 1974-1998. Acta Oncol. 2004;43:57-64.

Ready to submit your research? Choose BMC and benefit from:

- fast, convenient online submission

- thorough peer review by experienced researchers in your field

- rapid publication on acceptance

- support for research data, including large and complex data types

- gold Open Access which fosters wider collaboration and increased citations

- maximum visibility for your research: over $100 \mathrm{M}$ website views per year

At BMC, research is always in progress.

Learn more biomedcentral.com/submissions 